\title{
Effect of insulin levels on the phosphorylation of specific amino acid residues in IRS-1: Implications for burn-induced insulin resistance
}

\author{
XIAO-MING LU, VICTORIA F. HAMRAHI, RONALD G. TOMPKINS and ALAN J. FISCHMAN
}

Surgical Service, Massachusetts General Hospital, Shriners Hospitals for Children and

Harvard Medical School, Boston, MA 02114, USA

Received April 22, 2009; Accepted June 16, 2009

DOI: 10.3892/ijmm_00000262

\begin{abstract}
Alterations in the phosphorylation and/or degradation of insulin receptor substrate-1 (IRS-1) produced by burn injury may be responsible, at least in part, for burninduced insulin resistance. In particular, following burn injury, reductions in glucose uptake by skeletal muscle may be secondary to altered abundance and/or phosphorylation of IRS-1. In this study, we performed in vitro experiments with 293 cells transfected with IRS-1. These studies demonstrated that there is a dramatic change in the phosphorylation pattern of Tyr, Ser and Thr residues in IRS-1 as a function of insulin levels. Specifically, Ser and Thr residues in the C-terminal region were phosphorylated only at high insulin levels. SILAC (stable isotope labeling with amino acids in cell culture) followed by sequencing of C-terminal IRS-1 fragments by tandem mass spectrometry demonstrated that there is significant protein cleavage at these sites. These findings suggest that one of the biological roles of the C-terminal region of IRS-1 may be negative modulation of the finely coordinated insulin signaling system. Clearly, this could represent an important factor in insulin resistance, and identification of kinase inhibitors that are responsible for the phosphorylation may foster new lines of research for the development of drugs for treating insulin resistance.
\end{abstract}

\section{Introduction}

The maintenance of glucose levels represents one of the most tightly regulated systems in the body. All cells require glucose,

Correspondence to: Dr Alan J. Fischman, Shriners Hospital for Children, 51 Blossom Street, Boston, MA 02114, USA

E-mail: aajjff@gmail.com

Abbreviations: ESI, electrospray ionization; DDA, data-dependent acquisition; IRS-1, insulin receptor substrate-1; PTM, posttranslational modification; Q-TOF, tandem quadrupole time-offlight mass spectrometry; SILAC, stable isotope labeling with amino acids in cell culture

Key words: insulin receptor substrate-1, phosphorylation, degradation, kinase, MS/MS, SILAC but glucose is only available from what is ingested or produced by the liver. Since glucose cannot be stored in significant amount except as glycogen in the liver and muscle, glucose transport into the cell by specific transporter proteins is critical for cell function. Insulin plays a major role in the maintenance of normal glucose levels. Thus, when blood glucose levels rise, insulin secretion is stimulated resulting in increased uptake by skeletal muscle via glucose transporter proteins and decreased glucose production by the liver. There appears to be several key proteins in the insulin/glucose regulatory cascade including insulin receptor substrate-1 (IRS-1). When levels of insulin and glucose are abnormally high in the fasting state, a condition called insulin resistance exists.

Hyperglycemia and glucose intolerance are frequently associated with the metabolic response to major trauma. Following injury $(1,2)$, burn shock $(3,4)$ or systemic infection $(5,6)$, oral and intravenous glucose tolerance tests have demonstrated delayed disposal of glucose from plasma into tissues. This 'diabetes of injury' could be explained if there was an insulin deficiency, and several studies $(1,3,7)$ have shown that early after trauma ('ebb phase') insulin concentrations are reduced even in the face of hyperglycemia. After resuscitation of trauma patients ('flow phase'), ß-cell responsiveness to glucose administration normalizes, and plasma insulin levels are appropriate or even higher than expected $(3,7)$. However, despite this appropriate acute insulin response to glucose administration, glucose intolerance and hyperglycemia continue. This finding suggests that certain tissues in trauma patients are relatively insensitive to the effects of insulin.

Although the number of investigations addressing the mechanism(s) of insulin resistance in trauma patients is limited, one significant study using the euglycemic insulin clamp technique demonstrated that i) the maximal rate of glucose disposal is reduced in trauma patients; ii) the metabolic clearance rate of insulin is almost twice as normal in these patients; and iii) post-trauma insulin resistance appears to occur in peripheral tissues, particularly skeletal muscle, and is consistent with a post-receptor effect (8). Unfortunately, the procedures used in this study were not capable of independently assessing the contributions of glucose transport, phosphorylation, and subsequent intracellular metabolism of glucose. Another study revealed that burn injury to rats 
results in impaired insulin-stimulated transport of $\left[{ }^{3} \mathrm{H}\right] 2$ deoxyglucose into soleus muscle strips in vitro (9). These investigators also demonstrated that insulin-stimulated phosphoinositide 3-kinase (PI 3-kinase) activity, pivotal for glucose transport in muscle by glucose transporter 4 (GLUT 4), was decreased by burn injury to rats as measured by its IRS-1associated activity. These data are consistent with alterations in post-receptor signaling following burn injury, which results in burn-induced insulin resistance.

There are numerous reports that describe insulin resistance in burn patients and animal models $(7,10-27)$. Insulin resistance is defined as elevated insulin levels in the presence of normal or elevated glucose levels. Direct measurements show that liver and skeletal muscle are resistant tissues (7). Lipolysis is not attenuated in trauma patients after glucose administration (15). Although the precise mechanism for insulin resistance produced by burns or other stressors is unknown, it is likely that insulin binding to membrane receptors is unchanged and post-receptor mechanism(s) are of greater importance (10).

Alterations in cytokine levels, such as TNF, IL-1 and IL-6, in burn patients and animal models of burn injury have been reported by our laboratory and by other investigators (28). Infusion of endotoxin, TNF and IL-1 can produce alterations in glucose metabolism and insulin resistance in vivo $(29,30)$. In addition, it has also been shown that endotoxin (31) and IL-6 (32) can produce insulin resistance in isolated hepatocyte cultures. It was demonstrated that IL- 6 inhibits the stimulation of glucokinase by insulin in isolated hepatocytes (32). Cortisol, glucagon and epinephrine can also produce insulin resistance (33). These molecules oppose the actions of insulin and are termed counter-regulatory hormones. Since these counter-regulatory hormones are elevated, at least initially after burn injury, it has been proposed that they may play a part in burn-induced insulin resistance. The levels of cytokines and counter-regulatory hormones are dramatically altered in burn patients and animal models (24,33-35). It also has been demonstrated that TNF suppresses insulin-induced tyrosine phosphorylation of insulin receptor and inhibits signaling from the insulin receptor $(36,37)$. Furthermore, the insulin resistance produced in spontaneously obese rats can be overcome by pretreatment of the animals with antibodies to TNF (38).

Dynamic and stress-dependent multi-site phosphorylations of IRS-1 tyrosine, serine and threonine residues have been described to have both positive and negative insulin effects. Tyrosine phosphorylation, in the $\mathrm{N}$ - or C-terminal regions of IRS-1 are generally considered to be positive posttranslational modifications (PTM) in insulin signaling pathways. In contrast, phosphorylation of serine and threonine residues at the $\mathrm{C}$-terminal region is usually considered to be negative PTMs; however, some positive effects of serine phosphorylation have been reported. A number of IRS-1 phosphorylation sites have been identified using different approaches such as radiolabeling with $\left[\gamma^{-32} \mathrm{p}\right]$-ATP (39-43), immunoblotting with anti-phosphopeptide antibodies (44-53), studies with mutated IRS-1 (54-56) and on- or off-line HPLC interfaced with MALDI-TOF or ESI-TOF (57-61). The large variation and poor reproducibility of reported phosphorylation sites can be explained by method sensitivities, enzymatic and chemical stabilities of the phosphorylated sites and the dosages/timing of stimuli. Proposed mechanisms for impairment of the insulin signaling system by phosphorylation of serine and threonine residues include feedback inhibition, cooperative interactions, uncoupling of the protein signaling network (62-66) and ubiquitin-proteasome degradation (67-73). It is fair to state that, to date, the ability of insulin to alter the phosphorylation patterns of IRS-1 is poorly understood. Since the negative biological effects of IRS-1 C-terminal phosphorylation may provide clues for exploring the mechanism of insulin resistance (74-78) after burn injury (79-82), evaluation of this issue has become a major focus of our laboratory.

In this study, we used nano-LC interfaced with tandem mass spectrometry to pin-point IRS-1 phosphorylation sites in a well-defined in vitro system. An N-terminal-specific $\mathrm{mAb}$, generated in our laboratory, was used for studying the phosphorylation pattern of IRS-1 after treatment with varying concentrations of insulin. Stable isotope labeling with amino acids in cell culture (SILAC) measurements indicated that at least $50 \%$ of IRS- 1 was degraded in our studies (insulin, $1 \mu \mathrm{M}$; $10 \mathrm{~min})$. Thus, the phosphorylation sites and SILAC results predicted that multiple fragmentations may occur in the middle of the C-terminus of IRS-1. In order to capture these informative IRS-1 fragments, a commercially available C-terminal-specific mAb was used in conjunction with SDSPAGE. MS/MS sequence data unambiguously confirmed (for the first time) the two predicted IRS-1 fragments with apparent MW's of $\sim 80$ and $\sim 65 \mathrm{kDa}$ on SDS-PAGE. The multiple cleavages at the C-terminus of IRS- 1 were attributed to phosphorylation at $\mathrm{Thr}^{475}, \mathrm{Thr}^{477}(80 \mathrm{kDa})$ and $\operatorname{Ser}^{641}(65 \mathrm{kDa})$ by sequence analysis. These results may provide pharmaceutical targets for producing drugs that inhibit sequencespecific Ser/Thr kinases. These reagents may normalize metabolic alterations, such as abnormal cytokine release and altered protein catabolism, which are associated with insulin resistance in critically ill patients with burn injuries.

\section{Materials and methods}

Chemicals. Acetonitrile (ACN, LC-MS Chromasolv), formic acid (FA), glacial acetic acid, LC-MS grade water, [Glu ${ }^{1}$ fibrinopeptide B and 2-mercaptoethanol were obtained from Sigma Chemical Co. (St. Louis, MO). SDS-PAGE Ready gels (7.5\% Tris-HCl), Laemmli sample buffer (cat. no. 161-0737) and Coomassie brilliant blue R-250 (cat. no. 161-0436) were obtained from Bio-Rad. Trypsin profile IGD kits (cat. no. PP0100) were obtained from Sigma. Anti-IRS-1 monoclonal antibody (cat. no. 05-699) and recombinant IRS-1 were purchased from Upstate (Charlottesville, VA). Insulin, potassium bisperoxo(bipyridine)oxovanadate, calyculin A (Discodermia calyx) and SILAC phosphoprotein identification kits (cat. no. SP10001) were products of Invitrogene (Carlsbad, CA). Protein G agarose beads were purchased from Pierce (Rockford, IL).

Preparation of monoclonal antibodies to IRS-1. Monoclonal antibodies were generated using traditional methods. Briefly, BALB-C mice were immunized with 5-100 $\mu \mathrm{g}$ of protein in 25-50 $\mu 1$ of Freud's Complete Adjuvant (Sigma) in 4 to 6 
subcutaneous sites. The material used for immunization was a GST fusion protein containing 150 amino acids from the $\mathrm{N}$ terminus of IRS-1 (MASPPESDGFSDVRKVGYLRKPK SMHKRFFVLRAASEAGGPARLEYYENEKKWRHK SSAPKRSIPLESCFNINKRADSKNKHLVALYTRDEHFAI AADSEAEQDSWYQALLQLHNRAKGHHDGAAALGAG GGGGSCSGSSGLGEAGEDLS). The same immunogen (in 25-50 $\mu 1$ of Freund's Incomplete Adjuvant) was used for 'booster' injections (4-6 subcutaneous sites) in the animals at two-week intervals. Once suitable blood titers were obtained, spleen cells were harvested and fused (PEG method) with SP 2/0 myeloma cells to generate hybridomas secreting monoclonal antibodies recognizing IRS-1 protein. These procedures, as well as all animal handling protocols, were reviewed and approved by the local animal study review board. The animals were housed and handled at the institution's AAALAC accredited facilities. Three mAb (3D10, 4C6 and $5 \mathrm{G} 7)$ were protein $\mathrm{G}$ purified and stored $(0.1 \mathrm{M}$ bicarbonate buffer, $\mathrm{pH}$ 9.2) at $-70^{\circ} \mathrm{C}$. Screening of these antibodies was performed against recombinant IRS-1, and antibodies were selected using both the highest tryptic peptide coverage and MS/MS sequence scores.

Transfection of 293 mammalian cells with recombinant IRS-1. An appropriate plasmid was prepared by subcloning of IRS-1tagged plasmid PCMVIRS transfected into DH5 $\alpha$ competent $E$. coli (Invitrogen). The transformed $E$. coli were incubated on Luria Broth plates with ampicillin. Single colonies were picked and incubated in Luria Broth medium with ampicillin, and the plasmids were purified using the Purelink Hipure Plasmid DNA Purification Maxiprep System (Invitrogen). Mammalian 293 cells, supplied from the American Type Culture Collection, were transfected with the recombinant IRS-1-tagged plasmid using a liposome reagent (Invitrogen) and Opti-MEM medium (Gibco) to deliver the plasmid DNA into the cells. IRS-1 expression was checked by Western blot analysis. Anti-IRS-1 (mouse) monoclonal primary antibody (Sigma) and Cell Signaling anti-mouse IgG HRP-linked secondary antibody (GE Healthcare) as well as anti-IRS-1 primary (rabbit) (Upstate) and Cell Signaling antirabbit IgG HRP-linked secondary antibody (GE Healthcare) were used to probe the blots.

Insulin stimulation. Mammalian 293 cells transfected with recombinant IRS-1 were grown to confluence and placed in serum-free Dulbecco's modified Eagle's medium (DMEM) for $2 \mathrm{~h}$. The cells were then treated with insulin $(0,50,100$, $150,250,500,750$ and $1000 \mathrm{nM}$ ) for $10 \mathrm{~min}$. Twelve culture plates for each insulin concentration were used for phosphorylation studies. After insulin treatment, the medium was aspirated, and the cells were lysed in Reporter lysis buffer with phosphatase cocktail inhibitors containing $50 \mathrm{nM}$ potassium bisperoxo(bipyridine)oxovanadate and $5 \mathrm{nM}$ calyculin $\mathrm{A}$ (Discodermia calyx) at $4^{\circ} \mathrm{C}$. SILAC was performed at an insulin concentration of $1 \mu \mathrm{M}$ for $10 \mathrm{~min}$ according to the SILAC Phosphoprotein Identification Kit protocol (Invitrogen, SP10001) with $\left[\mathrm{U}-{ }^{13} \mathrm{C}_{6}\right]$-L-lysine and $\left[\mathrm{U}-{ }^{13} \mathrm{C}_{6}\right]$-L-arginine.

Immunoprecipitation of human IRS-1 and its C-terminal fragments. Intact IRS-1 was immunoprecipitated with selected N-terminal-specific mAb $(5 \mathrm{G} 7,5 \mu \mathrm{g})$ and prewashed with protein $\mathrm{G}$ agarose beads (50 $\mu 1$ packed volume). The reaction mixtures were gently stirred in PBS $(200 \mu 1)$ at $4^{\circ} \mathrm{C}$ for $1 \mathrm{~h}$, and excess $\mathrm{mAb}$ was removed with PBS $(1 \mathrm{ml} \times 3)$. Cell lysates (containing human IRS-1 with total proteins $\sim 2.5 \mathrm{mg} / \mathrm{ml}, 3 \mathrm{ml}$ for each IP) were centrifuged at $14,000 \mathrm{x} \mathrm{g}$ for $2 \mathrm{~min}$ and filtered $(0.22 \mu \mathrm{m})$ at $4^{\circ} \mathrm{C}$. The processed cell lysates and washed immunobeads were gently stirred at $4^{\circ} \mathrm{C}$ for $2 \mathrm{~h}$. The immunocomplex beads were centrifuged at $14,000 \times \mathrm{g}$ for $15 \mathrm{sec}$ and washed with PBS $(1 \mathrm{ml} \mathrm{x} 3$, for 2 min each). IRS-1 was released, and cysteine residues were alkylated with Laemmli sample buffer (with 5\% 2-mercaptoethanol, $50 \mu \mathrm{l}$ ) for $5 \mathrm{~min}$ at $95^{\circ} \mathrm{C}$ and then $1 \mathrm{~h}$ at room temperature with stirring. The reaction mixtures were separated by SDS-PAGE (7.5\% Tris- $\mathrm{HCl}$, Ready gels), The IRS-1 bands stained with Coomassie brilliant blue R-250 were excised, and in-gel trypsin digestion was performed $\left(0.2 \mu \mathrm{g}\right.$ trypsin in $70 \mu \mathrm{l}$ reaction buffer, $37^{\circ} \mathrm{C}$, overnight $)$.

Fragments of IRS-1 C-terminal were immunoprecipitated with $\mathrm{mAb}$ raised to the first $\mathrm{C}$-terminal 14 amino acid residues of IRS-1 (05-699, clone 1M92-7, Upstate) using the methods described above.

Nano-LC interfaced with Q-TOF tandem mass spectrometry. The phosphorylated peptides induced with various insulin dosages were analyzed by nano-LC coupled to a Q-TOF hybrid mass spectrometer from Micromass; equipped with an in-house fabricated electrospray (PicoTip emitter, FS360-2010-D-20-C7, New Objective) and operated in the positive ion mode. Chromatographic separation was achieved using a C18 PepMap300 column (5- $\mu \mathrm{m}, 75-\mu \mathrm{m}$ I.D. x $15-\mathrm{cm}$ length, LC Packings). HPLC gradient elution $(160 \mathrm{nl} / \mathrm{min})$ was performed with mobile phase A (water $98 \%$, acetonitrile $2 \%$, formic acid $0.1 \%$ ) and mobile phase B (acetonitrile $/ 0.1 \%$ formic acid) starting with $2 \% \mathrm{~B}, 2$ min isocratic, up to $80 \% \mathrm{~B}$ over 25 min (linear gradient), 10 min of isocratic elution with $80 \% \mathrm{~B}$, and a return to $2 \% \mathrm{~B}$ over $5 \mathrm{~min}$. The column was reconditioned with the starting mobile phase for $30 \mathrm{~min}$ before the next analysis. The digested peptide mixture $(5 \mu \mathrm{l})$ was trapped and desalted with a $\mu$-Precolumn Cartridge (PepMap C18, 5- $\mu \mathrm{m}, 300-\mu \mathrm{m}$ I.D. x 5 mm, LC Packings) for $2 \mathrm{~min}$ at a flow rate of $15 \mu \mathrm{l} / \mathrm{min}$. [Glu ${ }^{1}$ ]-fibrinopeptide $\mathrm{B}$ (100 fmol/ $/ \mu 1$ constant infusion, Sigma) was used for mass calibration. Optimized Q-TOF conditions were: ESI capillary voltage, $3500 \mathrm{~V}$; cone voltage, $35 \mathrm{~V}$; source temperature $80^{\circ} \mathrm{C}$. Quadrupole-1 was set to bandwidth bypass mode, and the TOF analyzer was scanned over m/z 400 to 1200 with a 1-sec integration time (mass resolution was 5500 FWHM at a mass of 785.84). Data were recorded in continuum DDA mode under CE 5V. Phosphorylated peptides were manually checked in order to reduce false-positive discoveries.

\section{Results and Discussion}

Screenings of the three anti-IRS-1 mAbs (3D10, 4C6 and $5 \mathrm{G} 7$ ) were performed based on each mAb's immunoprecipitated IRS-1 sequence coverage as well as sequence scores obtained with Q-TOF tandem mass spectrometry (Table I). A total of 11 tryptic peptides of human IRS-1 expressed in the cell line was found to have satisfactory 
Table I. Screening results for 3 monoclonal antibodies. ${ }^{a}$

\begin{tabular}{|c|c|c|c|c|c|c|}
\hline Tryptic ID & Sequences & Charge & MS theory & 3D10 & $4 \mathrm{C} 6$ & $5 \mathrm{G} 7$ \\
\hline T19 & 82-HLVALYTR-89 & 2 & 971.56 & & & 88 \\
\hline $\mathrm{T} 23$ & 162-EVWQVILKPK-171 & 2 & 1238.74 & & & 191 \\
\hline T28 & 197-LNSEAAAVVLQLMNIR-227 & 2 & 1740.96 & & & 56 \\
\hline $\mathrm{T} 45-46$ & 365-LHPPLNHSRSIPMPASR-381 & 2 & 1909.01 & & 31 & \\
\hline T51 & 444-SVTPDSLGHTPPAR-457 & 2 & 1434.73 & & & 166 \\
\hline T63 & 581-SYPEEGLEMHPLER-594 & 2 & 1685.77 & 53 & & \\
\hline T66-67 & 627-KGSGDYMPMSPK-638 & 2 & 1296.58 & & 25 & \\
\hline T68 & 639-SVSAPQQIINPIR-651 & 2 & 1421.80 & & 173 & 154 \\
\hline T92 & 952-AAWQESTGVEMGR-964 & 2 & 1420.64 & & 91 & 165 \\
\hline T96 & 999-QSYVDTSPAAPVSYADMR-1016 & 2 & 1956.89 & 37 & & 58 \\
\hline T97 & 1017-TGIAAEEVSLPR-1028 & 2 & 1241.66 & 58 & 145 & 188 \\
\hline
\end{tabular}

${ }^{\mathrm{a}} \mathrm{MS} / \mathrm{MS}$ scores were obtained from MassLynx 4.1.

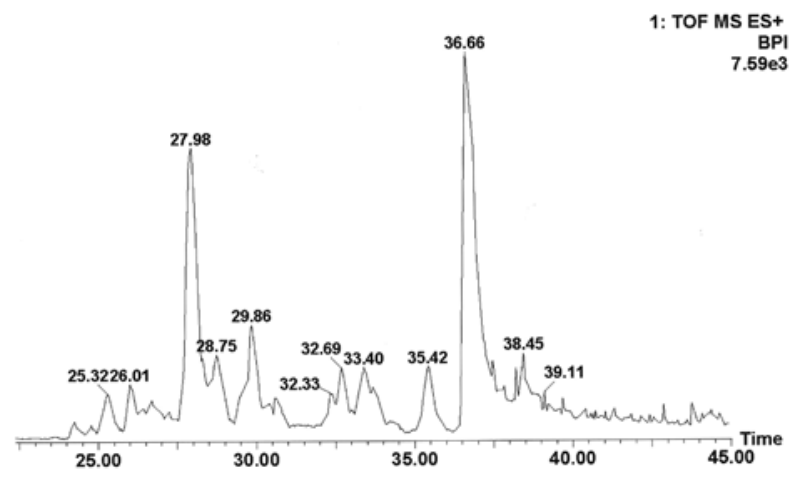

Figure 1. Nano-LC base peak ion chromatogram of human IRS-1 tryptic peptides. Column: C18 PepMap 300 column $(5-\mu \mathrm{m}, 75-\mu \mathrm{m}$ I.D. x 15-cm length). Flow rate: $160 \mathrm{nl} / \mathrm{min}$. Desalting column: $\mu$-Precolumn Cartridge (PepMap C18, 5- $\mu \mathrm{m}, 300-\mu \mathrm{m}$ I.D. x $5 \mathrm{~mm}$, LC Packings) for $2 \mathrm{~min}$ at a flow rate of $15 \mu 1 / \mathrm{min}$. Gradient conditions are described in the text.

MS/MS scores using PepSeq of MassLynx v4.1 software. Since the reproducibility of the sequencing results (Table I) indicated that mAb (5G7) was the optimal choice, it was used for the in vitro studies of insulin effects.

A total of 260 IRS-1 tryptic peptides, both doubly and triply charged under electrospray ionization, was located within the Q-TOF mass survey window (from m/z 400 to 1200). The chromatographic elution time window was $\sim 30 \mathrm{~min}$ with the nano-LC gradient conditions that were employed; it was impossible to chromatographically separate the digested IRS-1 peptide mixture at the single peptide level since many of the tryptic peptides that were eluted overlapped. In other words, at any given retention time, several peptides were able to be recognized by the mass survey. To overcome these problems, 6 precursor ions which can be selected for MS/MS sequence analysis from a single MS survey scan (precursor ion charge state recognitions under ESI) were selected to provide secondary mass resolution as supplementation to the chromatographic separation. False-positive precursor ions attributed to contaminations were eliminated by MS/MS

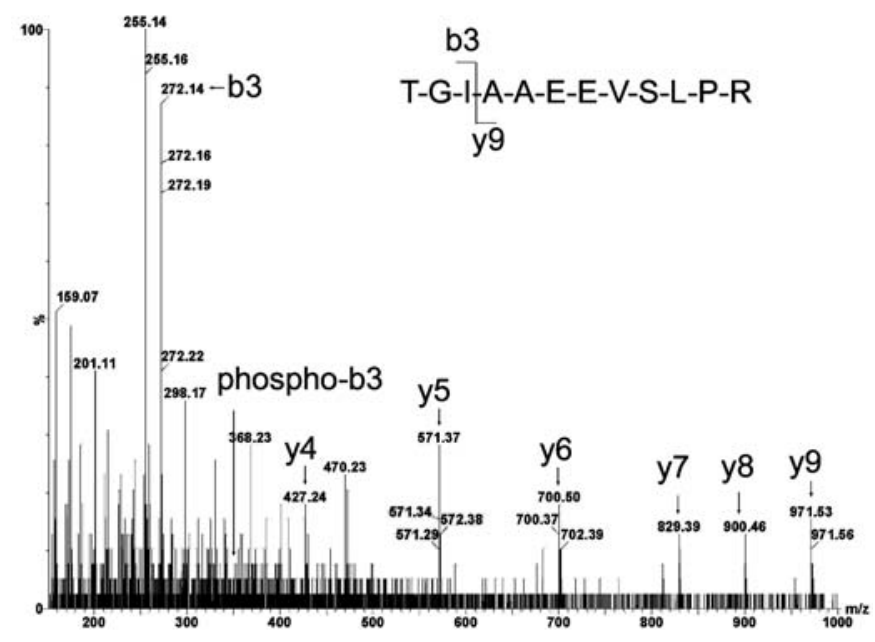

Figure 2. MS/MS sequence analysis of the $\mathrm{pThr}^{1017}$ peptide detected with DDA: doubly charged, $[\mathrm{M}+2 \mathrm{H}]^{2+}(\mathrm{m} / \mathrm{z}=621.84)$, 1017-TGIAAEEVSLPR$1028{ }^{1017}$ Thr-Gly-Ile, non-phosphorylated b3 ion $(\mathrm{m} / \mathrm{z}=272.16)$ and corresponding phosphorylated b3 ion $(\mathrm{m} / \mathrm{z}=352.13)$ were observed after insulin stimulation.

sequence analysis. The nano-LC Q-TOF settings described above do have false-negative discoveries; these missed precursor ions may have had weak hydrophobic properties (escaping from the trapping $\mathrm{C} 18$ column that was used for desalting), weak ionizations and/or chemical alterations in predictable peptide structures. However, the positively identified precursor ions under our experimental conditions represented desirable candidate peptides for the phosphorylation studies at the proteomic level. Thus, unambiguously discovered peptides were selected as relative MS fingerprints for IRS-1 protein expression and post-translational modification analysis in the insulin treatment studies. A representative nano-LC chromatogram of in-gel trypsindigested IRS-1 is shown in Fig. 1.

The in vitro IRS-1 phosphorylation pattern as a function of increasing insulin concentration is shown in Table II. The 
Table II. Effect of insulin concentration on the human IRS-1 phosphorylation pattern.

\begin{tabular}{|c|c|c|c|c|c|c|c|c|}
\hline Insulin (nM) & 0 & 50 & 100 & 150 & 250 & 500 & 750 & 1000 \\
\hline \multirow[t]{6}{*}{ Sites } & $\mathrm{pSer}^{323}$ & $\mathrm{pSer}^{308}$ & $\mathrm{pSer}^{323}$ & $\mathrm{pSer}^{308}$ & $\mathrm{pSer}^{323}$ & $\mathrm{pSer}^{641}$ & $\mathrm{pSer}^{641}$ & $\mathrm{pSer}^{641}$ \\
\hline & pThr ${ }^{305}$ & pThr ${ }^{305}$ & $\mathrm{pSer}^{1132}$ & $\mathrm{pSer}^{641}$ & $\mathrm{pSer}^{486}$ & pThr ${ }^{475}$ & pThr ${ }^{475}$ & pThr ${ }^{475}$ \\
\hline & & pTyr $^{1001}$ & pTyr ${ }^{1001}$ & pThr ${ }^{1116}$ & $\mathrm{pSer}^{641}$ & pThr ${ }^{1017}$ & pThr ${ }^{1017}$ & pThr ${ }^{477}$ \\
\hline & & pTyr $^{1012}$ & pTyr $^{1012}$ & pTyr $^{558}$ & pTyr $^{558}$ & pTyr $^{558}$ & pTyr $^{558}$ & pThr ${ }^{1017}$ \\
\hline & & & & pTyr $^{1001}$ & pTyr $^{1001}$ & & & \\
\hline & & & & pTyr $^{1012}$ & pTyr $^{1012}$ & & & \\
\hline
\end{tabular}

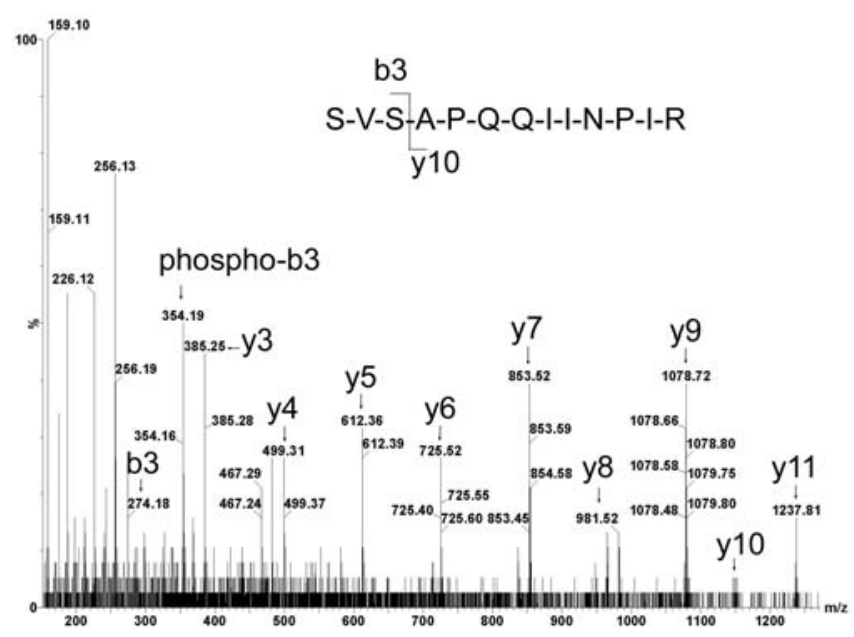

Figure 3. MS/MS sequence analysis of the $\mathrm{pSer}^{641}$ peptide detected with DDA: doubly charged, $[\mathrm{M}+2 \mathrm{H}]^{2+}(\mathrm{m} / \mathrm{z}=711.91)$, 639-SVSAPQQIINPIR$651{ }^{639}$ Ser-Val, b2 ion $(\mathrm{m} / \mathrm{z}=187.12)$. No corresponding phosphorylated ${ }^{639} \mathrm{Ser}$ b2 ion was observed (expected $\mathrm{m} / \mathrm{z}=267.09$ ). ${ }^{639}$ Ser-Val-Ser ${ }^{641}$, b3 ion $(\mathrm{m} / \mathrm{z}=274.14)$, phosphorylated $\mathrm{b} 3$ ion $(\mathrm{m} / \mathrm{z}=354.17)$ indicated phosphorylation at Ser $^{641}$ in control IRS-1.

phosphorylated sequence sites were assigned by 79.97-Da mass differences between phosphorylated b or y ions and corresponding non-phosphorylated ions at the 50-mDa mass accuracy of their centroid MS/MS spectra. Typical MS/MS sequences of insulin-dependent phosphorylation sites $\mathrm{pSer}^{641}$ and pThr ${ }^{1017}$ of IRS-1 are shown in Figs. 2 and 3.

The striking insulin-dependent phosphorylation pattern indicated that $\mathrm{pThr}^{475}$, $\mathrm{pThr}^{477}$ and $\mathrm{pSer}^{641}$ were induced by high levels of insulin. These phosphorylated sites provide the first clue toward understanding the negative effects of insulin (possibly via the ubiquitin-proteosome pathway) and suggest a possible mechanism for insulin resistance. SILAC was used to study the IRS-1 degradation at these phosphorylation sites at high insulin dosages $(1 \mu \mathrm{M}, 10 \mathrm{~min})$. Tryptic peptide T23 without phosphorylation (162-EVWQVILKPK-171) labeled with heavy isotopes (insulin stimulation) and light isotopes (without insulin) were used as a mass marker to evaluate IRS-1 phosphorylation under varying insulin conditions. Relative peak areas of precursor peptides indicated that at least $50 \%$ of IRS-1 was rapidly degraded. The critical question was whether IRS-1 degradation was triggered at the three phosphorylated sites. To address this question, two major Cterminal fragments at the cleavage sites $\mathrm{pThr}^{475}, \mathrm{pThr}^{477}$ and

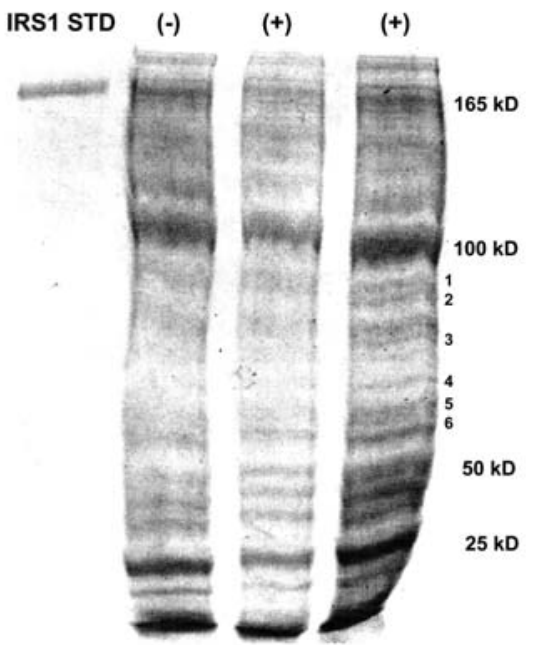

Figure 4. SDS-PAGE of fragmented human IRS-1 after insulin treatment (1000 nM, $10 \mathrm{~min})$. C-terminal mAb, 05-699 (5 $\mu \mathrm{g})$; protein $\mathrm{G}$ beads, $50 \mu 1$ (packed). Immunobeads were prepared at $4^{\circ} \mathrm{C}$ for $1 \mathrm{~h}$ and washed with chilled PBS ( $1 \mathrm{ml} \mathrm{x} \mathrm{3).} \mathrm{Twelve} \mathrm{cell} \mathrm{culture} \mathrm{plates} \mathrm{were} \mathrm{evaluated.} \mathrm{Cell} \mathrm{lysates} \mathrm{were}$ filtered through $0.22-\mu \mathrm{m}$ membranes. Immunoprecipitation was performed at $4^{\circ} \mathrm{C}$ for $2 \mathrm{~h}$, and excess proteins were removed with three PBS washes. Ready gels $(7.5 \%$, Bio-Rad, $30 \mu 1$ per well) were used for separation, and protein bands were stained with Coomassie brilliant blue R-250. Left lane, rat IRS-1 as MW marker; next lane, $15 \mu 1$ of IP mixtures without insulin treatment (-), next lane $15 \mu 1$ of IP mixtures with insulin treatment $(+)$; right lane, $30 \mu 1$ of IP mixtures with insulin treatment (+). Human IRS-1 bands from the in vitro experiments corresponded to a slightly lower MW compared with the standard rat IRS-1 band. Fragment band \#1 ( $80 \mathrm{kDa})$ was confirmed with two sequences: 639-SVSAPQQIINPIR-651 and 1017-TGIAAEEVSLPR-1028, and fragment band \#4 ( 65 kDa) was confirmed with 1017-TGIAAEEVSLPR1028 .

pSer ${ }^{641}$ must be obtained for $50 \%$ degradation. The predicated C-terminal fragment cleaved at sites $\mathrm{pThr}^{475} \mathrm{pThr}^{477}$ was expected at 80,673 $\mathrm{Da}$ and the second fragment cleaved at site pSer $^{641}$ at $64,441 \mathrm{Da}$. When C-terminal-specific mAb $(05-699,5 \mu \mathrm{g})$ was used in the insulin stimulation study, SDS-PAGE showed that the IRS-1 band was reduced by $\sim 50 \%$ with $1000 \mathrm{nM}$ insulin (for $10 \mathrm{~min}$ ) as compared with the control; in agreement with the SILAC result. The multiple bands between $50 \mathrm{kDa}$ (IgG heavy chain) and $100 \mathrm{kDa}$ (dimer of IgG heavy chain; 2-mercaptoethanol is not sufficient for complete reduction of all disulfide bonds, Fig. 4) were excised, digested and subjected to nano-LC Q-TOF sequence analysis. Sequencing confirmed that the human IRS-1 bands in Fig. 4 were slightly lower in MW than rat IRS-1 standard ( 165 kDa). The fragment band represented by band \#1 ( 80 kDa 
estimated from SDS-PAGE) was confirmed with two human IRS-1 sequences: 639-SVSAPQQIINPIR-651 and 1017TGIAAEEVSLPR-1028. Also, the cleavage site precursor ion (472-GPS TL $_{\mathrm{P}}$ TAPNGHYILSR-487) was no longer detected. The fragment represented by band \#4 ( $65 \mathrm{kDa}$ from SDS-PAGE) was confirmed only with 1017-TGIAAEEV SLPR-1028, whereas, the precursor ion (639-SV $\mathrm{P}$ SAPQQII NPIR-651) corresponding to this cleavage was missing from our MS survey list. These three observations confirm an inhibitory mechanism at high insulin conditions; stressed cells treated with high concentrations of insulin activate unknown kinases to phosphorylate threonine and serine residues located in the middle of the C-terminus of IRS-1, and the multiple phosphorylated sites may trigger the ubiquitinproteosome pathway. The C-terminus of IRS-1 cleaved around $\mathrm{pThr}^{475}$ and $\mathrm{pThr}^{477}$ afforded a fragment with MW $\sim 80 \mathrm{kDa}$, while the fragment with $\mathrm{MW} \sim 65 \mathrm{kDa}$ was related to $\mathrm{pSer}^{641}$. The observations that serine phosphorylation decreases insulin-stimulated tyrosine phosphorylation of IRS-1 (83) and proteolytic turnover of the protein (84) suggest that the IRS-1 function is modulated by both positive (N-terminal) and negative (C-terminal) mechanisms. Negative modulation is associate with serine phosphorylation at the $\mathrm{N}$ terminus of the protein; with the C-terminal boundary at residue 574 (85). Ser/Thr kinases, such as mTOR/S6k and Akt1, may be involved in C-terminal cleavages triggered by multi-site phosphorylation. In contrast, positive signaling effects at low insulin levels were associated with $\mathrm{pSer}^{308}$, $\mathrm{pThr}^{305}$ and $\mathrm{pTyr}^{1012}$. Phosphorylated $\mathrm{Tyr}^{1012}$ may be one of the downstream SH2 domain binding sites, since it possesses the characteristic YADM sequence. Thus, sequence-specific Ser/Thr kinases may be pharmaceutical targets for modulating insulin resistance.

In conclusion, the observed effects of insulin concentration on the phosphorylation pattern of IRS-1 represents an important factor in insulin resistance. C-terminal cleavages may be produced at specific phosphorylated Ser/Thr sites. Also, two major C-terminal fragments (sequenced with tandem MS) point to the left boundary of the C-terminus as an important region for negative modulatory effects. In the future, identification of kinase inhibitors which are responsible for phosphorylation may foster new lines of research for the development of drugs for treating insulin resistance (86).

\section{References}

1. Carey LC, Lowery BD and Cloutier CT: Blood sugar and insulin response of humans in shock. Ann Surg 172: 342-350, 1970.

2. Thomsen V: Studies in trauma and carbohydrate metabolism with special reference to the existence of traumatic diabetes. Acta Med Scand 96: 1-416, 1938.

3. Allison SP, Hinton P and Chamberlain MJ: Intravenous glucose-tolerance, insulin, and free-fatty-acid levels in burned patients. Lancet 2: 1113-1116, 1968.

4. Taylor FHL, Levenson SM and Adams MA: Abnormal carbohydrate metabolism in human thermal burns. N Engl J Med 231: 437-445, 1944.

5. Rayfield EJ, Curnow RT, George DT and Beisel WR: Impaired carbohydrate metabolism during a mild viral illness. N Engl J Med 289: 618-621, 1973.

6. Williams JL and Dick GF: Decreased dextrose tolerance in acute infectious disease. Arch Intern Med 50: 801-818, 1932.

7. Wilmore DW, Mason AD and Pruitt BA: Insulin response to glucose in hypermetabolic burn patients. Ann Surg 183: 314-320, 1976.
8. Wilmore DW, Aulick HL and Goodwin CW: Glucose metabolism after severe injury. Acta Chir Scand (Suppl) 498: 43-47, 1980.

9. Ikezu T, Okamoto T, Yonezawa K, et al: Analysis of thermal injury-induced insulin resistance in rodents. Implication of postreceptor mechanisms. J Biol Chem 272: 25289-25295, 1997.

10. Mizock BA: Alterations in carbohydrate metabolism during stress: a review of the literature. Am J Med 98: 75-84, 1995.

11. Grecos GP, Abbott WC, Schiller WR, Long CL, Birkhahn RH and Blakemore WS: The effect of major thermal injury and carbohydrate-free intake on serum triglycerides, insulin and 3methylhistidine excretion. Ann Surg 200: 632-637, 1984.

12. Thomas R, Aikawa $\mathrm{N}$ and Burke JF: Insulin resistance in peripheral tissues after a burn injury. Surgery 86: 742-747, 1979.

13. Turinsky J and Patterson SA: Proximity of a burn wound as a new factor in considerations of postburn insulin resistance. J Surg Res 26: 171-174, 1979 .

14. Woolfson AMJ, Heatley RV and Allison SP: Insulin to inhibit protein catabolism after injury. N Engl J Med 300: 14-17, 1979.

15. Wolfe RR, Drukot MJ and Wolfe MH: Effect of thermal injury on energy metabolism, substrate kinetics and hormonal concentrations. Circ Shock 9: 383-394, 1982.

16. Hinton PS, Allison SP, Littlejohn S and Lloyd J: Insulin and glucose to reduce catabolic response to injury in burned patients. Lancet 1: 767-769, 1971.

17. Allison SP, Hinton $\mathrm{P}$ and Chamberlain MJ: Intravenous glucose-tolerance, insulin, and free fatty-acid levels in burned patients. Lancet 2: 113-116, 1968 .

18. Wolfe RR, Durkot MJ, Allsop JR and Burke JF: Glucose metabolism in severely burned patients. Metab Clin Exp 28: 1031-1039, 1979.

19. Jahoor F, Herndon DN and Wolfe RR: Role of insulin and glucagon in the response of glucose and alanine kinetics in burninjured patients. J Clin Invest 78: 807-814, 1986.

20. Jahoor F, Shangraw RE, Miyoshi H, Wallfish H, Herndon DN and Wolfe RR: Role of insulin and glucose oxidation in mediating the protein catabolism of burns and sepsis. Am J Physiol 257: E323-E331, 1989.

21. Black PR, Brooks DC, Bessey PQ, Wolfe RR and Wilmore DW: Mechanism of insulin resistance following injury. Ann Surg 196: 420-435, 1982.

22. Frayn KN: Effects of burn injury on insulin secretion and sensitivity to insulin in the rat in vivo. Eur J Clin Invest 5: 331-337, 1975.

23. Allsop JR, Wolfe RR and Burke JF: Glucose kinetics and responsiveness to insulin in the rat injured by burn. Surg Gynecol Obstet 147: 565-573, 1978.

24. Frayn KN, Le Marchand-Brustel Y and Freychet P: Studies on the mechanism of insulin resistance after injury in the mouse. Diabetologia 14: 337-341, 1978

25. Turinsky J, Saba TM, Scovil WA and Chesnut T: Dynamics of insulin secretion and resistance after burns. J Trauma 17: 344-350, 1977.

26. Turinsky J: Glucose metabolism in the region recovering from burn injury: effect of insulin on 2-deoxyglucose uptake in vivo. Endocrinology 113: 1370-1376, 1983

27. Wogensen L, Jensen M, Svensson P, Worsaae H, Welinder B and Nerup J: Pancreatic beta-cell function and interleukin-1 beta in plasma during the acute phase response in patients with major burn injuries. Eur J Clin Invest 23: 311-319, 1993.

28. Mester MM, Carter EA, Tompkins RG, Gelfand JA, Dinarello CA, Burke JF and Clark BD: Thermal injury induces very early production of interleukin-1 alpha in the rat by mechanisms other than endotoxemia. Surgery 115: 588-596, 1994.

29. Lang CH, Dobrescu C and Burke JF: Tumor necrosis factor impairs insulin action on peripheral glucose disposal and hepatic glucose output. Endocrinology 130: 43-52, 1992.

30. Ling PR, Bristrian BR, Mendez B and Igtfan NW: Effects of systemic infusion of endotoxin, tumor necrosis factor, and interleukin-1 on glucose metabolism in the rat: relationship to endogenous glucose production and peripheral tissue glucose uptake. Metabolism 43: 279-284, 1994.

31. Portoles MT, Pagan R, Ainaga MJ, Diaz-Laviada I and Municio AM: Lipopolysaccharide-induced insulin resistance in monolayers of cultured hepatocytes. Br J Exp Pathol 70: 199-205, 1989.

32. Christ B: Inhibition by recombinant human interleukin-6 of the glucagon-dependent induction of phosphopyruvate carboxykinase gene expression in cultured rat hepatocytes: regulation of gene transcription and messenger RNA degradation. Hepatology 20: $1577-1583,1994$ 
33. Cryer PE: Hypoglycemia: the limiting factor in the management of IDDM. Diabetes 43: 1378-1389, 1994.

34. De Bandt JP, Chollet-Martin S, Hernvann A, Lioret N, du Roure LD, Lim SK, Vaubourdolle M, Guiechot J, Saizy R, Giboudeau J, et al: Cytokine response to burn injury: relationship with protein metabolism. J Trauma 36: 624-628, 1994.

35. Burke JF, Wolfe RR, Mullanye J, Matthews DE and Bier DM: Glucose requirements following burn injury. Ann Surg 190: 274-283, 1979

36. Feinstein R, Kanetyh H, Papa MZ, Lunenfield B and Karazik A: Tumor necrosis factor alpha suppresses insulin-induced tyrosine phosphorylation of insulin receptor and its substrates. J Biol Chem 268: 26055-26058, 1993.

37. Hotamisligil GS, Murray DL, Choy LN and Spiegelman BM: Tumor necrosis factor inhibits signaling from the insulin receptor. Proc Natl Acad Sci USA 91: 4854-4858, 1994.

38. Hotamisligil GS: Reduced tyrosine kinase activity of the insulin receptor in obesity-diabetes: central role of tumor necrosis factor. J Clin Invest 94: 1543-1549, 1994.

39. Sun XJ, Crimmins DL, Myers MG, Miralpeix M and White MF: Pleiotropic insulin signals are engaged by multisite phosphorylation of IRS-1. Mol Cell Biol 13: 7418-7428, 1993.

40. Liberman Z and Eldar-Finkelman H: Serine 332 phosphorylation of insulin receptor substrate-1 by glycogen synthase kinase-3 attenuates insulin signaling. J Biol Chem 280 : 4422-4428, 2005.

41. De Fea K and Roth RA: Protein kinase C modulation of insulin receptor substrate-1 tyrosine phosphorylation requires serine 612. Biochemistry 36: 12930-12947, 1997.

42. Goodyear LJ, Giorgino F, Sherman LA, Carey J, Smith RJ, and Dohm GL: Insulin receptor phosphorylation, insulin receptor substrate-1 phosphorylation, and phosphatidylinositol 3-kinase activity are decreased in intact skeletal muscle strips from obese subjects. J Clin Invest 95: 2195-2204, 1995.

43. Tanasijevic MJ, Myers MG, Thoma RS, Crimmins DL, White MF and Sacks DB: Phosphorylation of the insulin receptor substrate IRS-1 by casein kinase II. J Biol Chem 268: 18157-18166, 1993.

44. Giraud J, Hass M, Feener EP, Copps KD, Dong X, Dunn SL and White MF: Phosphorylation of IRS1 at Ser-522 inhibits insulin signaling. Mol Endocrinol 21: 2294-2302, 2007.

45. Luo M, Langlais P, Yi Z, Lefort N, Filippis EAD, Hwang H, Christ-Roberts CY and Mandarino LJ: Phosphorylation of human insulin receptor substrate-1 at serine 629 plays a positive role in insulin signaling. Endocrinology 148: 4895-4905, 2007

46. Scioscia M, Gumaa K, Kunjara S, Paine MA, Selvaggi LE, Rodeck $\mathrm{CH}$ and Rademacher TW: Insulin resistance in human preeclamptic placenta is mediated by serine phosphorylation of insulin receptor substrate-1 and -2. J Clin Endocrinol 91: 709-717, 2006.

47. Nawaratne R, Gray A, Jogensen CH, Downes CP, Siddle K and Sethi JK: Regulation of insulin receptor substrate 1 pleckstrin homology domain by protein kinase C: role of serine 24 phosphorylation. Mol Endocrinol 20: 1838-1852, 2006.

48. Danielsson A, Ost A, Nystrom FH and Strafors P: Attenuation of insulin-stimulated insulin receptor substrate- 1 serine 307 phosphorylation in insulin resistance of type 2 diabetes. J Biol Chem 280: 34389-34392, 2005.

49. Li Y, Soos TJ, Li X, Wu J, DeGennaro M, Sun X, Littman DR, Birnbaum MJ and Polajiewicz RD: Protein kinase C theta inhibits insulin signaling by phosphorylation IRS1 at Ser1101. J Biol Chem 279: 45304-45307, 2004.

50. Gao Z, Zuberi A, Quon MJ, Dong Z and Ye J: Aspirin inhibits serine phosphorylation of insulin receptor substrate 1 in tumor necrosis factor-treated cells through targeting multiple serine kinase. J Biol Chem 278: 24944-24950, 2003.

51. Hers I, Bell CJ, Poole AW, Jiang D, Denton RM, Schaefer E and Tavare JM: Reciprocal feedback regulation of insulin receptor and insulin receptor substrate tyrosine phosphorylation by phosphoinositide 3-kinase in primary adipocytes. Biochem J 368: 875-884, 2002

52. Yu C, Chen Y, Cline GW, Zhang D, Zong H, Wang Y, Bergeron R, Kim JK, Cushman SW, Cooney GJ, Atcheson B, White MF, Kraegen EW and Shulman GI: Mechanism by white fatty acids inhibit insulin activation of insulin receptor substrate-1 (IRS-1)-associated phosphatidylinositol 3-kinase activity in muscle. J Biol Chem 277: 50230-50236, 2002.

53. Amoui M, Craddock BP and Miller WT: Differential phosphorylation of IRS-1 by insulin and insulin-like growth factor 1 receptors in Chinese hamster ovary cells. J Endocrinol 171: $153-162,2001$
54. Gual P, Gremeaux T, Gonzalez T, Marchand-Brustel YL and Tanti JF: MAP kinase and mTOR mediate insulin-induced phosphorylation of insulin receptor substrate-1 on serine residues 307, 612 and 632. Diabetologia 46: 1532-1542, 2003.

55. Werner ED, Lee J, Hansen L, Yuan M and Shoelson SE: Insulin resistance due to phosphorylation of insulin receptor substrate-1 at serine 302. J Biol Chem 279: 35298-35305, 2004

56. Sommerfeld MR, Metzger S, Stosik M, Tennagels N and Eckel J: In vitro phosphorylation of insulin receptor substrate 1 by protein kinase C-zeta: Functional analysis and identification of novel phosphorylation sites. Biochemistry 43: 5888-5901, 2004.

57. Lehr S, Kotzka J, Herkner A, Sikmann A, Meyer HE, Krone W and Muller-Wieland D: Identification of major tyrosine phosphorylation sites in the human insulin receptor substrate Gab-1 by insulin kinase receptor kinase in vitro. Biochemistry 39: 10898-10907, 2000.

58. Luo M, Reyna S, Wang L, Yi Z, Carroll C, Dong LQ, Langlais P, Weintraub ST and Mandarino LJ: Identification of insulin receptor substrate 1 serine/threonine phosphorylation sites using mass spectrometry analysis: Regulatory role of serine 1223 . Endocrinology 146: 4410-4416, 2005.

59. Yi Z, Luo M, Carroll CA, Weintraub ST and Mandarino LJ: Identification of phosphorylation sites in insulin receptor substrate- 1 by hypothesis-driven high-performance liquid chromatography-electrospray ionization tandem mass spectrometry. Anal Chem 77: 5693-5699, 2005.

60. Yi Z, Luo M, Mandarino LJ, Reyna SM, Carroll CA and Weintraub ST: Quantification of phosphorylation of insulin receptor substrate-1 by HPLC-ESI-MS/MS. J Am Soc Mass Spectrom 17: 562-567, 2006.

61. Beck A, Moeschel K, Deeg M, Haring HU, Voelter W, Schleicher ED and Lehmann R: Identification of an in vitro insulin receptor substrate-1 phosphorylation site by negative-ion mLC/ES-API-CID-MS hybrid scan technique. J Am Soc Mass Spectrom 14: 401-405, 2003.

62. Gual P, Marchand-Brustel YL and Tanti JF: Positive and negative regulation of insulin signaling through IRS-1 phosphorylation. Biochimie 87: 99-109, 2005.

63. Zick Y: Ser/Thr phosphorylation of IRS proteins: A molecular basis for insulin resistance. www.stke.org/cgi/content/full/ sigtrans;2005/268/pe4

64. Liu YF, Herschkovitz A, Boura-Halfon S, Ronen D, Paz K, LeRoith and Zick Y: Serine phosphorylation proximal to its phosphotyrosine binding domain inhibits insulin receptor substrate 1 function and promotes insulin resistance. Mol Cell Biol 24: 9668-9681, 2004.

65. Zick Y: Insulin resistance: a phosphorylation-based uncoupling of insulin signaling. Trends Cell Biol 11: 437-441, 2001

66. Bouzakri K, Karlsson HKR, Vestergaard H, Madsbad S, Christiansen E and Zierath JR: IRS-1 serine phosphorylation and insulin resistance in skeletal muscle from pancreas transplant recipients. Diabetes 55: 785-791, 2006.

67. Sugita H, Fujimoto M, Yasukawa T, Shimizu N, Sugita M, Yasuhara S, Martyn JM and Kaneki M: Inducible nitric-oxide synthase and NO donor induce insulin receptor substrate-1 degradation in skeletal muscle cells. J Biol Chem 280: 14203-14211, 2005.

68. Usui I, Imamura T, Huang J, Satoh H, Shenoy SK, Lefkowitz RJ, Hupfeld CJ and Olefsky JM: $\beta$-arrestin-1 competitively inhibits insulin-induced ubiquitination and degradation of insulin receptor substrate 1. Mol Cell Biol 24: 8929-8937, 2004.

69. Pederson T, Kramer DL and Rondinone CM: Serine/threonine phosphorylation of IRS 1 triggers its degradation, possible regulation by tyrosine phosphorylation. Diabetes 50: 24-31, 2001.

70. Potashnik R, Bloch-Damti A, Bashan N and Rudich A: IRS1 degradation and increased serine phosphorylation cannot predict the degree of metabolic insulin resistance induced by oxidative stress. Diabetologia 46: 639-648, 2003.

71. Lee AV, Gooch JL, Oesterreich S, Guler RL and Yee D: Insulin-like growth factor 1-induced degradation of insulin receptor substrate 1 is mediated by the $26 \mathrm{~S}$ proteasome and blocked by phosphatidylinositol 3'-kinase inhibition. Mol Cell Biol 20: 1489-1507, 2000.

72. Sun XJ, Goldberg JL, Qiao LY and Mitchell JJ: Insulin-induced insulin receptor substrate-1 degradation is mediated by the proteasome degradation pathway. Diabetes 48: 1359-1364, 1999.

73. Zhande R, Michell JJ, Wu J and Sun XJ: Molecular mechanism of insulin-induced degradation of insulin receptor substrate 1 . Mol Cell Biol 22: 1016-1026, 2002. 
74. White MF: Insulin signaling in health and disease. Science 302 : 1710-1711, 2003.

75. White MF: IRS proteins and the common path to diabetes. Am J Physiol Endocrinol Metab 283: E413-E422, 2002.

76. Taniguchi CM, Emanuelli B and Kahn CR: Critical nodes in signaling pathways: insights into insulin action. Nat Rev Mol Cell Biol 7: 85-96, 2006.

77. Thirone AC, Huang C and Klip A: Tissue-specific roles of IRS proteins in insulin signaling and glucose transport. Trends Endocrinol Metab 17: 72-78, 2006.

78. Youngren JF: Regulation of insulin receptor function. Cell Mol Life Sci 64: 873-891, 2007.

79. Zhang Q, Carter EA, Ma BY, White M, Fischman AJ and Tompkins RG: Molecular mechanism(s) of burn-induced insulin resistance in murine skeletal muscle: role of IRS phosphorylation. Life Sci 77: 3068-3077, 2005.

80. Carter EA, Burks D, Fischman AJ, White M and Tompkins RG: Insulin resistance in thermally-injured rats is associated with post-receptor alteration in skeletal muscle, liver and adipose tissue. Int J Mol Med 14: 653-658, 2004.

81. Lu XM, Lu M, Tompkins RG and Fischman AJ: Site-specific detection of S-nitrosylated PKB $\alpha /$ Akt1 from rat soleus muscle using CapLC-Q-TOFmicro mass spectrometry. J Mass Spectrom 40: 1140-1148, 2005
82. Lu XM, Lu M, Fischman AJ and Tompkins RG: A new approach for sequencing human IRS1 phosphotyrosine-containing peptides using CapLC-Q-TOFmicro. J Mass Spectrom 40: 599-607, 2005.

83. Tanti JF, Gremeaux T, van Obberghen E and Le MarchandBrustel Y: Serine/threonine phosphorylation of insulin receptor substrate 1 modulate insulin receptor signaling. J Biol Chem 269: 6051-6057, 1994.

84. Haruta T, Uno T, Kawahara J, Takano A, Egawa K, Sharma PM, Olefsky JM and Kobayashi M: A rapamycin-serine pathway down-regulates insulin signaling via phosphorylation and proteasomal degradation of insulin receptor substrate-1. Mol Endocrinol 14: 783-794, 2000.

85. Xu X, Sarikas A, Dias-Santagata DC, Dolios G, Lafontant PJ, Tsai SC, Zhu W, Nakajima H, Nakajima HO, Field LJ, Wang R and Pan ZQ: The CUL7 E3 ubiquitin ligase targets insulin receptor substrate 1 for ubiquitin-dependent degradation. Mol Cell 30: 403-414, 2008.

86. Wing SS: The UPS in diabetes and obesity. BMC Biochem 9: S6, 2008. 